\title{
PENGARUH PEMBERDAYAAN MASYARAKAT DALAM MENGOLAH HASIL LAUT MENJADI MP ASI TERHADAP EKONOMI
}

\author{
Yessy Nur Endah Sary, Tutik Hidayati \\ Sekolah Tinggi Ilmu Kesehatan Hafshawaty Pesantren Zainul Hasan \\ Email : yessynurendahsari@gmail.com
}

\begin{abstract}
ABSTRAK
Pangan dan gizi merupakan faktor penting serta mendasar dalam menentukan kualitas sumber daya manusia dan tingkat kehidupan masyarakat. Berdasarkan studi pendahuluan pada bulan April 2017 didapatkan data bahwa Probolinggo mendapat peringkat kedua untuk daerah gizi kurang di Jawa Timur. Di Tahun 2016 terdapat 200 balita yang mengalami gizi kurang tepatnya di Pesisir Kalibuntu Kabupaten Probolinggo. Tujuan dari penelitian ini adalah untuk menganalisis pengaruh pemberdayaan masyarakat dalam mengolah hasil laut menjadi MP ASI terhadap gizi balita dan ekonomi. Penelitian ini dilakukan di Pesisir Kalibuntu Kabupaten Probolinggo. Penelitian ini merupakan penelitian eksperimental. Populasi adalah semua ibu yang mempunyai balita dengan gizi kurang di Pesisir Kalibuntu Kabupaten Probolinggo sebanyak 200 orang. Teknik sampling menggunakan simple random sampling. Sampel adalah sebagian ibu rumah tangga yang tidak bekerja di Pesisir Kalibuntu Kabupaten Probolinggo sebanyak 160 orang. Analisis data univariat menggunakan distribusi frekuensi.Analisis Bivariat menggunakan wilcoxon match paired test nilai $\mathrm{p}$ value $0,000<\alpha$ 0,05. Analisis Multivariat menggunakan regresi linier berganda. Besarnya nilai Exp (B) pada analisis regresi linier berganda status gizi memiliki nilai 0,279 yang berarti bahwa status gizi memiliki peluang 0,279 kali untuk berubah. Sedangkan variabel ekonomi pada regresi linier berganda memiliki nilai Exp (B) sebesar 65,933, dari hasil tersebut dapat dijelaskan bahwa ekonomi memiliki peluang meningkat 65,933 kali. Diharapkan untuk tenaga kesehatan khususnya bidan untuk lebih meningkatkan kualitas pemberian pendidikan kesehatan kepada masyarakat tentang gizi kurang, gizi buruk dan dampaknya bagi balita untuk pertumbuhan dan perkembangannya.
\end{abstract}

Kata Kunci : pemberdayaan masyarakat, Gizi Balita, Ekonomi

\begin{abstract}
Food and nutrition are important and fundamental factors in determining the quality of human resources and the level of community life. Based on a preliminary study in April 2017, data was obtained that Probolinggo was ranked second for under nutrition in East Java. In 2016 there were 200 toddlers who experienced inappropriate nutrition in the Kalibuntu Coast of Probolinggo Regency. The purpose of this study was to analyze the effect of community empowerment in processing marine products into MP ASI on toddler nutrition and the economy. This research was conducted in the Kalibuntu Coast of Probolinggo Regency. This research is an experimental research. The population is all mothers who have children under five with malnutrition in the Kalibuntu Coast of Probolinggo Regency as many as 200 people. The sampling technique uses simple random sampling. The sample was some housewives who did not work in the Kalibuntu Coast of Probolinggo Regency as many as 160 people. Univariate data analysis using frequency distribution. Bivariate analysis using Wilcoxon match paired test $p$ value of $0,000<\alpha 0,05$. Multivariate analysis using multiple linear regression. The amount of $\operatorname{Exp}(B)$ value in multiple linear regression analysis nutritional status has a value of 0.279, which means that nutritional status has a 0.279 times chance to change. While the economic variables in multiple linear regression have Exp $(B)$ value of 65,933, from these results it can be explained that the economy has an opportunity to increase 65,933 times. It is expected for health workers, especially midwives, to further improve the quality of providing health education to the community about lack of nutrition, malnutrition and its impact on children under five for growth and development.
\end{abstract}

Keywords : Community empowerment, Toddler Nutrition, Economic

\section{PENDAHULUAN}

Upaya pembangunan perlu diarahkan untuk menumbuhkan sikap kemandirian dalam diri manusia dan masyarakat Indonesia melalui peningkatan peran serta, efisiensi, dan produktivitas rakyat dalam rangka meningkatkan taraf hidup, kecerdasan lahir batin.

Tujuan pembangunan nasional dalam GBHN adalah peningkatan kecerdasan dan produktivitas tenaga kerja, untuk terciptanya masyarakat Indonesia yang berkualiats tinggi. Pangan dan gizi 
merupakan faktor penting serta mendasar dalam menentukan kualitas sumberdaya manusia dan tingkat kehidupan masyarakat. Sejalan dengan itu upaya perlu direspon yang positif sehubungan dengan upaya peningkatan, penganeka ragaman, penyediaan bahan makanan sekaligus upaya peningkatan pendapatan masyarakat melalui pengembangan potensi makanan lokal.

Probolinggo terletak hampir di ujung paling timur Pulau Jawa. Probolinggo merupakan daerah yang luas yang sebagian besar wilayahnya berada di pinggir pantai utara pulau Jawa. Wilayah Kabupaten Probolinggo terutama Persisir Kalibuntu sangat kaya akan hasil laut terutama ikan, kerang, cumi-cumi serta hasil tangkapan lainnya. Pesisir Kalibuntu strategis untuk pengembangan usaha yang berkaitan dengan hasil perikanan sehingga dapat menjadikan daerah ini sejahtera. Tetapi pada kenyataanya, mayoritas penduduk Pesisir Kalibuntu adalah nelayan miskin dengan pendidikan yang sangat rendah bahkan banyak yang tidak bersekolah. Mayoritas hasil tangkapan laut dijual langsung kepada pedagang tengkulak dari luar daerah atau langsung dijual ke pasar tanpa diolah terlebih dahulu. Hal inilah yang membuat harga jual hasil tangkapan laut rendah. Berbeda halnya jika hasil tangkapan laut tersebut diolah terlebih dahulu misalnya dijadikan olahan ikan, abon, makanan awetan yang kemudian bisa diedarkan di supermarket pastilah harganya akan lebih mahal. Karena keterbatasan dana dan sumber daya manusia, maka potensi tersebut tidak bisa dimaksimalkan. Tujuan Penelitian untuk menganalisis pengaruh pemberdayaan, untuk menganalisis Pengaruh Pemberdayaan Masyarakat Dalam Mengolah Hasil Laut Menjadi MP ASI Terhadap Ekonomi. Manfaat Penelitian agar masyarakat paham bahwa hasil laut dapat dimaksimalkan unutk diolah dan dijual sehingga mampu menambah penghasilan masyarakat sekitar.

\section{METODE}

Penelitian ini merupakan penelitian eksperimental. Populasi adalah semua ibu yang mempunyai balita dengan gizi kurang di Pesisir Kalibuntu Kabupaten Probolinggo sebanyak 200 orang. Menggunakan Simple Random Sampling. Sampel adalah sebagian ibu rumah tangga yang tidak bekerja di Pesisir Kalibuntu Kabupaten Probolinggo sebanyak 160 orang. Pengumpulan Observasi dan Wawancara. Analisis Univariat menggunakan distribusi frekuensi.Analisis Bivariat menggunakan wilcoxon match paired test.

\section{HASIL DAN PEMBAHASAN \\ Analisis Univariat \\ Pekerjaan Kepala Keluarga}

Tabel 1 Distribusi frekuensi responden berdasarkan pekerjaan kepala keluarga

\begin{tabular}{lll}
\hline Jenis Pekerjaan & Frekuensi & Persentase \\
\hline Nelayan & 106 & $66.3 \%$ \\
Buruh Nelayan & 9 & $5.6 \%$ \\
Pedagang & 24 & $15.0 \%$ \\
Tukang bangunan & 9 & $5.6 \%$ \\
Tukang Becak & 4 & $2.5 \%$ \\
Montir & 8 & $5.0 \%$ \\
\hline Jumlah & 160 & $100 \%$ \\
\hline
\end{tabular}

Berdasarkan tabel 1 diketahui bahwa sebagian besar responden yaitu 106 orang kepala keluarga (66,3\%) bekerja sebagai nelayan.

Tabel 2 Distribusi frekuensi ekonomi sebelum pemberdayaan masyarakat dalam mengolah hasil laut.

\begin{tabular}{lll}
\hline Ekonomi & Frekuensi & Persentase \\
\hline Rendah $(<\mathrm{UMK})$ & 160 & $100 \%$ \\
Tinggi(>UMK) & 0 & 0 \\
\hline Jumlah & 160 & $100 \%$ \\
\hline
\end{tabular}

Berdasarkan tabel 2 diketahui bahwa pendapatan semua penduduk di Desa Kalibuntu sebelum dilakukan pemberdayaan masyarakat dalam mengolah hasil laut adalah rendah, yaitu sebanyak 160 orang $(100 \%)$ 


\section{Ekonomi Sesudah Pemberdayaan}

Tabel 3 Distribusi frekuensi ekonomi sesudah pemberdayaan masyarakat dalam mengolah hasil laut.

\begin{tabular}{lll}
\hline Ekonomi & Frekuensi & Persentase \\
\hline Rendah $(<$ UMK) & 71 & $44,38 \%$ \\
Tinggi(>UMK) & 89 & $55,62 \%$ \\
\hline Jumlah & 160 & $100 \%$ \\
\hline
\end{tabular}

Berdasarkan tabel 3 diketahui bahwa mayoritas pendapatan penduduk di Desa Kalibuntu setelah dilakukan pemberdayaan masyarakat dalam

mengolah hasil laut adalah tinggi yaitu sebanyak 89 orang $(55,62 \%)$.

Tabel 4 Distribusi frekuensi pemberdayaan masyarakat dalam mengolah hasil laut

\begin{tabular}{lll}
\hline Pemberdayaan & Frekuensi & Persentase \\
\hline Baik & 106 & $66,25 \%$ \\
Kurang & 54 & $33,75 \%$ \\
\hline Jumlah & 160 & $100 \%$ \\
\hline
\end{tabular}

Berdasarkan tabel 4 diketahui bahwa pemberdayaan masyarakat dalam mengolah hasil laut menjadi MP-
ASI adalah baik, yaitu sebanyak 106 orang $(66,25 \%)$

\section{Analisis Bivariat}

Gizi balita sebelum dan sesudah pemberdayaan

Tabel 5 Tabulasi silang gizi balita sebelum dan sesudah pemberdayaan masyarakat dalam mengolah hasil laut menjadi MP ASI.

\begin{tabular}{|c|c|c|c|c|c|c|c|c|c|c|}
\hline \multirow{3}{*}{$\begin{array}{lrr}\text { Pengaruh } & \text { Pemberdayaan } \\
\text { Masyarakat } & \text { Dalam } \\
\text { Mengolah Hasil } & \text { Laut } \\
\text { Menjadi MP ASI } & \end{array}$} & \multicolumn{8}{|c|}{ Gizi Balita } & \multirow{2}{*}{\multicolumn{2}{|c|}{ Jumlah }} \\
\hline & \multicolumn{2}{|c|}{ Gizi Buruk } & \multicolumn{2}{|c|}{ Gizi Kurang } & \multicolumn{2}{|c|}{ Gizi Baik } & \multicolumn{2}{|c|}{$\begin{array}{c}\text { Gizi } \\
\text { Lebih }\end{array}$} & & \\
\hline & $\mathrm{F}$ & $\%$ & $\mathrm{~F}$ & $\%$ & $\mathrm{~F}$ & $\%$ & $\mathrm{~F}$ & $\%$ & $\mathrm{~F}$ & $\%$ \\
\hline Sebelum Pemberdayaan & 10 & 6,25 & 51 & 31,87 & 98 & 61,25 & 1 & 0,63 & 160 & 100 \\
\hline Sesudah Pemberdayaan & 0 & 0 & 3 & 1,88 & 157 & 98,12 & 0 & 0 & 160 & 100 \\
\hline $\mathrm{Z}=\quad \mathrm{p}=0,001 \quad \alpha=0.05$ & & & & & & & & & & \\
\hline
\end{tabular}

Berdasarkan tabel 5 di atas diketahui bahwa sudah tidak ada responden yang menderita gizi buruk $(0 \%)$, yang mengalami gizi kurang sebanyak 3 responden $(1,88 \%)$, yang menjadi gizi baik sebanyak 157 responden $(98,12 \%)$ dan tidak ada yang berstatus gizi lebih $(0 \%)$.

Hasil uji wilcoxon match paired test antara pemberdayaan masyarakat dalam mengolah hasil laut menjadi MP ASI dengan status gizi diperoleh nilai $\mathrm{p}$ value $0,001<\alpha 0,05$, maka ha diterima sehingga ada pengaruh pemberdayaan masyarakat dalam mengolah hasil laut menjadi MP ASI terhadap status gizi balita.

\section{Ekonomi sebelum dan sesuah pemberdayaan}

Tabel 6 Tabulasi silang ekonomi sebelum dan sesuah pemberdayaan masyarakat dalam mengolah hasil laut menjadi MP ASI

\begin{tabular}{|l|l|l|l|l|l|l|}
\hline \multirow{2}{*}{$\begin{array}{c}\text { Pengaruh Pemberdayaan Masyarakat Dalam } \\
\text { Mengolah Hasil Laut Menjadi MP ASI }\end{array}$} & \multicolumn{3}{|c|}{ Ekonomi } & \multirow{2}{*}{ Jumlah } & \multirow{2}{*}{$\%$} \\
\cline { 2 - 7 } & Rendah (<UMK) & Tinggi (>UMK) & & \\
\cline { 2 - 7 } & F & $\%$ & F & $\%$ & F & 5 \\
\hline Sebelum Pemberdayaan & 160 & 100 & 0 & 0 & 160 & 0 \\
\hline Sesudah Pemberdayaan & 71 & 44,38 & 89 & 55,62 & 160 & 100 \\
\hline $\mathrm{Z}=\mathrm{p}=0.00 \quad \alpha=0.05$ & & & & & & \\
\hline
\end{tabular}


Tabel 6 Tabel silang menunjukkan bahwa setelah pemberdayaan ekonomi masyarakat meningkat menjadi tinggi yaitu sebanyak 89 $(55,62 \%)$ dibandingkan sebelum pemberdayaan yang semuanya berpendapatan ekonomi rendah yaitu 160 orang (100\%).
Hasil uji wilcoxon match paired test antara pemberdayaan masyarakat dalam mengolah hasil laut menjadi MP ASI dengan ekonomi diperoleh nilai $\mathrm{p}$ value $0,000<\alpha 0,05$, maka ha diterima sehingga ada pengaruh pemberdayaan masyarakat dalam mengolah hasil laut menjadi MP ASI terhadap ekonomi.

\section{Analisia Multivariat}

Tabel 7 Hasil analisis regresi linier berganda

\begin{tabular}{llll}
\hline Variabel & Sig & $\operatorname{Exp}(\mathrm{B})$ & $\mathrm{CI}(95 \%)$ \\
\hline $\begin{array}{l}\text { Status } \\
\text { Gizi }\end{array}$ & 0,001 & 0,279 & $0,085-0,912$ \\
\hline Ekonomi & 0,000 & 65,933 & $20,718-209.827$ \\
\hline
\end{tabular}

Berdasarkan tabel 7 dapat dipahami bahwa status gizi memiliki nilai sig $0,001<0,05$ yang berarti pemberdayaan berpengaruh terhadap status gizi. Ekonomi memiliki nilai sig $0,000<0,005$ yang berarti pemberdayaan berpengaruh terhadap ekonomi.

Besarnya nilai Exp (B) pada analisis regresi linier berganda status gizi memiliki nilai 0,279 yang berarti bahwa status gizi memiliki peluang 0,279 kali untuk berubah. Sedangkan variabel ekonomi pada regresi linier berganda memiliki nilai Exp (B) sebesar 65,933, dari hasil tersebut dapat dijelaskan bahwa ekonomi memiliki peluang meningkat 65,933 kali.

\section{PEMBAHASAN}

Konsep pemberdayaan dalam wacana pembangunan masyarakat selalu dihubungkan dengan konsep mandiri, partisipasi, jaringan kerja, dan keadilan (Sri, 2011). Pada dasarnya pemberdayaan diletakkan pada kekuatan tingkat individu dan sosial (Sumardi, 2011). Partisipasi merupakan komponen penting dalam pembangkitan kemandirian dan proses pemberdayaan. Sebaiknya, orang-orang harus terlibat dalam proses tersebut sehingga mereka dapat lebih memperhatikan hidupnya untuk memperoleh rasa percaya diri, memiliki harga diri dan pengetahuan untuk mengembangkan keahlian baru. Prosesnya dilakukan secara kumulatif sehingga semakin banyak ketrampilan yang dimiliki seseorang, semakin baik kemampuan berpastisipasinya (Adhi,2016).

Pemberdayaan masyarakat dalam mengolah hasil laut menjadi MP-ASI dilakukan dengan beberapa tahap, yaitu: Memberikan motivasi, berinteraksi dan bekerja sama. Dalam perencanaan pemberdayaan masyarakat, peneliti bekerjasama dengan kepala desa setempat, bidan desa dan kader untuk mengundang masyarakat khususnya ibu yang memiliki balita dengan status gizi kurang dan gizi buruk untuk datang ke posyandu rutin yang diselenggarakan di awal bulan. Balita-balita tersebut ditimbang berat badannya dan diukur tinggi badannya untuk kemudian dianalisis status gizinya. Setelah itu, dijelaskan kepada ibu-ibu tersebut tentang kondisi anak mereka, penyebab dan bahaya jika tidak dilakukan penanganan terhadap status gizi balita dan pemberian motivasi.

Guna mendayagunakan potensi sosial ekonomi lokal. Peneliti juga bekerja sama dengan ahli gizi. Peran ahli gizi disini adalah memberikan penjelasan tentang status gizi baik, kurang, buruk dan lebih. Ahli gizi memaparkan penyebab dari terjadinya status gizi kurang dan buruk, bahaya dan cara penganggulangan sederhana untuk gizi kurang dan gizi buruk. Ahli gizi mengajari cara memilih hasil laut yang benar seperti ikan, cumi, kerang dan rumput lau, cara menghilangkan racun, cara menyimpan hail laut. Setelah hasil laut dipilih dengan kualitas baik, maka hasil laut tersebut dibersihkan dan dicampur dengan bahan-bahan untuk diolah dengan teknologi sederhana sehingga menghasilkan olahan yang siap dijadikan MP ASI seperti bakso ikan tongkol, sate cumi, nugget ikan, agar-agar dan manisan rumput laut yang tinggi protein dan vitamin untuk dikonsumsi balita (Ridawati, 2011).

Dalam hal memperkuat budaya kewirausahaan peneliti bekerja sama dengan ahli marketing untuk membantu melatih masyarakat dalam mengemas olahan hasil laut berupa MP ASI agar menarik dan siap diedarkan di pasar tradisional. Guna mengembangkan akses pasar Ahli marketing memaparkan cara yang tepat untuk memilih pasar, menghitung laba rugi dan kapan waktu yang tepat untuk mendistribusikan olahan MP ASI dari hasil laut tersebut.

\section{SIMPULAN}

Gizi balita dan ekonomi meningkat sesudah diadakaanya pemberdayaan masyarakat dalam mengolah hasil laut menjadi MP ASI 


\section{DAFTAR PUSTAKA}

Fitri, Rahmawati. 2015. Pengembangan Usaha Hasil Olahan Ikan Guna Meningkatkan Pnedapatan Masyarakat Peseisir Pantai Di Daerah Gunung Kidul. Prosiding Seminar Nasional "Research Month".

Sri, Tatin, Pakaya. Karakteristik Kerupuk Berbahan Dasar Sagu dengan Subtitusi dan Fortifikasi Rumput Laut. Jurnal Ilmiah Perikanan dan Kelautan. 2011. Volume II, Nomor 4:5-6

Sumardi. 2011. Ekonomi Dan Kemasyarakatan. Surabaya:Pena Biru
Adhi,dkk. 2016. Pemberdayaan Kader Desa Dan Tokoh Masyarakat Dalam Implementasi Strategi Deteksi Dini Kasus Malnutrisi Anak Balita Di Desa Bukit Karangasem. Jurnal Udayana Mengabdi, Volume 15 Nomor 1, Januari 2016

Ridawati, Marpaung. Analisis Organoleptik Pada Hasil Olahan Sosis Ikan Air LautDan Air Tawar. Jurnal Ilmiah Universitas Batanghari Jambi. 2011. Vol.11 No.3:7-8 